\title{
Entrevista com César Guimarães
}

Thais Florêncio de Aguiar ${ }^{1}$

\section{Desafios da conjuntura e armas da teoria política: golpe, democracia e fascismo}

Realizada em agosto deste ano, esta entrevista de Cesar Guimarães se converteu em um depoimento reflexivo sobre democracia, golpe de estado e fascismo. Lançando mão dos recursos da teoria política, Cesar lembra os momentos em que os golpes à democracia instauraram o fascismo por vias liberais, sentenciando: "a política não pode mais se nutrir de nada parecido com o liberalismo. Nada". Tendo como mote o golpe-impeachment de 2016, Cesar questiona o lugar do institucionalismo no pensamento político, evidenciando os mecanismos da relação entre golpe de estado e legalidade e, ainda, golpe de estado e governo representativo.

Um dos fundadores do antigo Iuperj, Cesar Guimarães é mestre de gerações de cientistas sociais atuantes hoje no país. Esta entrevista-depoimento integra o livro, ainda no prelo, "Cesar Guimarães, uma antologia de textos políticos", organizado por Thais Florêncio de Aguiar, Cristina Buarque de Hollanda e Pedro Villas Bôas Castelo Branco (IESP/UERJ). É preciso assinalar que a ironia, característica expressiva de Cesar Guimarães, se faz muito presente neste depoimento. Como o leitor pode notar, ela exerce espécie de função socrática, questionando ideias estabelecidas e provocando o senso crítico do leitor. 
Thais Florêncio de Aguiar: Cesar, sinta-se à vontade para dar os rumos que quiser a essa entrevista.

César Guimarães: Em primeiro lugar, Thais, obrigado por essa entrevista que será publicada no livro que Cristina Buarque, você e Pedro Villas Bôas Castelo Branco inventaram. Pretendo dar apenas um depoimento.

\section{Thais Florêncio de Aguiar:}

Nós só temos a agradecer por este depoimento.

\section{César Guimarães:}

Não sei se é cabível. O que tenho a dizer sobre a reflexão política de nosso tempo é coisa solta (na medida em que eu tenha algo a dizer sobre isso - coisa que eu duvido muito - porque, como dizem alguns, "meu tempo já passou!").

\section{Thais Florêncio de Aguiar:}

Sua obra é muito atenta aos desafios políticos de seu tempo. Esse é um traço marcante. Você não pensa no abstrato. Por isso, acho muito importante falarmos sobre a atual situação que, entre outras coisas, se relaciona com o golpe de 2016.

\section{César Guimarães:}

Acho necessário dizer algumas coisas antes de chegar lá. Na realidade, não gostaria de falar disso diretamente, porque é tão banal o fato de que houve um golpe de estado no país! Nem quero me dar esse trabalho. Várias pessoas melhores do que eu, juristas, cientistas políticos, sociólogos escreveram sobre isso. Muitos disseram que não houve golpe, já que as intuições contam e ainda vivem; outros disseram que houve golpe; outros ainda disseram que foi muito bom etc.

\section{Thais Florêncio de Aguiar:}

Certo. Passemos às questões que você deseja desenvolver em primeiro lugar.

\section{César Guimarães:}

Quero desenvolver dois pontos que tem a ver: 1) com a questão da institucionalidade ou das instituições como núcleo da reflexão política; e 2) com a conversa, por ocasião do golpe, que tive com meus amigos, basicamente, da área de política da UERJ (Maracanã). Antes de iniciar o primeiro ponto, desculpe o prefácio, mas me divirto muito com a ideia de que você começa a nossa conversa dizendo que a minha obra revela isto ou aquilo, porque a obra é tão pequena que mal merece a publicação que terá. Como todo mundo sabe, eu sou um ser falante, eu sou um professor, sou um mero divulgador de ideias alheias. Procuro fazer isso com certo talento ao longo da minha vida. E só! Para usar a literatura conhecida sobre isso, não sou alguém que rarefaz ideias alheias, mas também não as crio, não sou um criador, rendo tributo aos criadores, de Aristóteles aos notáveis cientistas políticos que temos no Brasil (não preciso citar nomes, porque não é o caso, posso esquecer gente).

\section{Thais Florêncio de Aguiar:}

Atentos para o seu enorme papel como professor ou "ser falante" que formou gerações de cientistas sociais, consideramos imprescindível publicar neste livro algumas de suas entrevistas.

\section{César Guimarães:}

Meu ponto inicial - temos conversado sobre isso, até porque você verá logo que você tem muito a ver com isso, Thais - é o que eu chamo, desculpa a retórica, de "Adeus à institucionalidade e às instituições!". Claro que sei que instituições e institucionalismo constituem o núcleo ou o paradigma dominante em qualquer de suas formas - há muitas formas de institucionalismo - na ciência política contemporânea ou pelo menos naquela que é escrita em língua inglesa; logo, é escrita em quase todo lugar. É da moda (leio em inglês se for preciso autores brasileiros; lamento só que autores americanos escrevam pouco em português. Mas isso é evidentemente natural. É como veneno de 
cobra, tudo muito natural). Pessoas admiráveis da ciência política contemporânea falam em institucionalismo histórico como forma, digamos - que termo horroroso! -, progressista de considerar o institucionalismo e seu conceito fundamental, a dependência de trajetória.

Evidentemente, é impossível esquecer ou reprimir - no sentido psicanalítico da palavra - que tudo isso tem origem na formulação notável de Douglass North, grande economista, que ganhou por isso o prêmio Nobel, e que é de um conservadorismo radical ou extremo. Mas isso pode ser esquecido e, portanto, a noção de dependência de trajetória pode ser usada à vontade, não é mesmo? É usada num sentido muito criativo, para falar coisas com que Douglass North não concordaria. Não tenho dúvida quanto a essa redução sociológica que se opera inclusive por aqui. A meu juízo, há uma espécie de determinismo retrospectivo que sentencia: "uma vez acontecido, as coisas continuarão sendo assim". Evidentemente, começa-se a usar matemática, geometria e tudo mais para melhorar a qualidade deste argumento. Isso é ruim, porque me livrei do determinismo liberal evidente que se chama progresso; livrei-me do determinismo marxista, bom e mal; e agora tenho que ouvir sobre um determinismo retrospectivo. Então, de certa maneira, isso toca pontos sensíveis da minha alma triste. Contudo, é o paradigma dominante na ciência política em todo lugar, no Brasil, inclusive. É paradigma muito forte, global e local. Está vinculado a uma forma qualquer de liberalismo, porque, como sabemos - não sou eu que digo, outros melhores do que eu já disseram -, há muitos liberalismos, há muitos republicanos, muitos libertarismos que povoam a universidade americana ou seus principais departamentos. Basta ter a pachorra de pesquisar na internet os principais departamentos de ciência política tal como atualmente nominados pela American Political Science Association. Daí, procure por "teoria política", veja o ranking (como você sabe, tem um ranking ou classificação para tudo). Você vai descobrir muitos autores e autoras, como eu descobri, que dizem "Eu sou feminista liberal!" ou "Eu sou liberal feminista.". Mas, quando não são? Nesse caso, são, enfim, outra coisa, comunitarista e por aí afora. Isso ocorre em Harvard, Yale, Princeton, Chicago, Stanford, Cornell e Berkeley também. Com exceção estranha de uma mulher que está chegando aos setenta anos, chamada Wendy Brown. Ademais, ela não compartilha do lamentável provincianismo de usar termos como "anarquia" que, na tradição popular, se vinculam à história da luta de operários que morreram no século XIX e, inclusive, foram mortos pela polícia nos anos 50 e 60 em Chicago. Isso foi esquecido. Senhor Nozik ${ }^{1}$ achou, por bem, usar esse termo em seu livro como se ele não existisse. Ou é desprezo, ou é ignorância provinciana. Temo que a segunda hipótese seja mais divertida. Voltando ao ponto, esses liberalismos todos, ao fim e ao cabo, são liberalismos que, por mais contrários que sejam, tendem a se unificar sob o termo geral de liberalismo - e, acrescento, de conservadorismo. Esses dois termos se fundem atualmente em oposição ao, digamos, comunismo, marxismo e toda essa coisa. É simples de entender por quê.

\section{Thais Florêncio de Aguiar:}

Por quê?

\section{César Guimarães:}

Porque o liberalismo é a doutrina política, é a doutrina dominante. Não só na universidade - não nos façamos de tão importantes -, mas no mundo global atual. Em qualquer lugar, não há, senão, liberais. Até o senhor Putin acha que é um liberal (o que é muito divertido). Evidentemente, o Senhor Trump é um desastrado, só faz bobagem, e não faz outra coisa senão a mesma política externa anterior. As cercas no México não são obra sua, as pessoas desconhecem que foram construídas há muito tempo. Salvo esses fantasminhas (como um sargentinho brasileiro que quer ser presidente) inventados por liberais de alma tranquila - são boas almas, como você sabe - 0 liberalismo é o ar político que o mundo respira.

\section{Thais Florêncio de Aguiar:}

De um lado, liberais. De outro, conservadores que se autointitulam liberais. Seria isso?

\section{César Guimarães:}

\footnotetext{
${ }^{1}$ Robert Nozick, autor de Anarquia, Estado e Utopia.
} 
Na verdade, houve uma fusão em termos ideológicos. Não há dois lados nessa guerra. Há um lado só. Uma fusão em termos globais e locais. Claro que as distinções vão reaparecer e aparecem na universidade. Mas, lamento muito, a universidade não dita o que o mundo pensa. É o contrário. 0 mundo pede à universidade que lhe forneça o que mais the importa. Quer dizer, aqueles que mandam no mundo, a elite de poderes nacionais, ainda existente, e a elite de poder global. Sobre os componentes, deixemos com um novo Wright Mills que haverá de escrever. Na verdade, já está escrito e não vou perder meu tempo com o elementar. Quem não gosta, fique à vontade. Essa coisa especular que é o liberalismo na universidade americana, aqui e alhures, é o que está em todo lugar.

\section{Thais Florêncio de Aguiar:}

O institucionalismo faz parte desse modo de pensar.

\section{César Guimarães:}

Sim, sim. É seu conceito-chave. As instituições funcionam e existe o Estado de Direito até para os refugiados e os imigrantes mais antigos na França. Não importa que haja estado de emergência, porque foi legalmente decretado. Então não tem problema, você circula muito tranquilamente, salvo bombas, não é verdade, na Place de la République. É muito desagradável morar em certos subúrbios, onde não se sabe por que existe o estado de exceção - palavra que é usada de maneira frequente e muito desagradavelmente pesada, não é? Está ali, está em todo lugar! Mas qual é a diferença entre isso e o morro do Alemão, hein?

\section{Thais Florêncio de Aguiar:}

Interessante como nesse vocabulário, os termos institucionalidade e regime de exceção convivem harmoniosamente hoje em dia.

\section{César Guimarães:}

Sim! Lamento informar que o mundo tornou-se isso. Quer dizer: instituições contam. Mas não contam mais, contam menos, tem menos importância. Não sou eu que estou dizendo, isso tudo é elementar. Há uma literatura vasta sobre isso, não vou citar nomes. É o que alguns autores chamam de desdemocratização, tanto global quanto local. De maneira que, até mesmo o que ocorre neste lamentável momento brasileiro, desde o golpe de estado que conduziu um senhor qualquer ao governo (o senhor Temer em Brasília) deve ser posto em perspectiva.

\section{Thais Florêncio de Aguiar:}

O nosso fado brasileiro é só uma faceta do que ocorre no global.

\section{César Guimarães:}

Tudo ocorre dentro da legalidade. O Brasil não inventou que se fazem impeachments legalmente ou "legitimamente", como cheguei a ouvir de pessoas não pouco importantes, notavelmente judiciosas. Quero crer que as diversas formas de liberalismo não têm mais o que nos dizer, não tem mais como fornecer elementos para aquilo que importa, que é a política. A política não acabou, sempre haverá política enquanto houver humanidade. Se não houver, não importa, é uma boa ideia pensar assim (essa expressão não é minha). A política não pode mais se nutrir de nada parecido com o liberalismo. Nada. Vão me perguntar: e os direitos? Os direitos, não se preocupem, foram conquistados a duras penas pelas massas ao longo de dois séculos! Isso ocorreu onde foi possível. Foi no ocidente. Essas lutas se deram no Japão? Sim. Antes da Segunda Guerra. Bom, mas agora o Japão fica no ocidente, eu não faço mais ideia. Isso se deu na China? Deu-se, sim senhor, no período de Sun Yat-Sen. Faz pouco tempo, não é? Complicado. E por aí vai. A expansão do ocidente levou isso para fora, sendo absorvido e relido. Muitos grupos de jovens cientistas políticos fazem hoje reviver o conceito de redução sociológica, uma belíssima ideia. A metrópole não impõe conceitos. Impõe, mas não adianta. A releitura é feita, e cedo ou tarde ela reaparece como o retorno do recalcado, sob a forma de política, de violência anticolonial, de guerra de guerrilha, de Che Guevara, seja lá o que for. Mesmo que sob formas mais brandas.

\section{Thais Florêncio de Aguiar:}


Fez-me lembrar de Frantz Fanon.

\section{César Guimarães:}

Bem lembrado. É verdade! Estou certo disso.

\section{Thais Florêncio de Aguiar:}

A questão da institucionalidade é apenas o primeiro ponto dessa conversa, certo?

\section{César Guimarães:}

Quero chamar atenção para isso que me toca, que me espanta. Não sei o que fazer com isso.

\section{Thais Florêncio de Aguiar:}

Acho que os cientistas políticos não sabem o que fazer. As instituições funcionam ao mesmo tempo em que vivemos uma brutal desdemocratização. Funcionam para isso?

\section{César Guimarães:}

Esse é o mundo que vivemos desde a crise de 2008 e que não acaba nunca. Como já foi dito por não poucos autores (não digo nada de novo), esse é o mundo do capitalismo triunfante. Zizek, com todo aquele brilho estranho - porque ele adora brilhar, não é verdade? - diz coisas muito interessantes: "A revolução está à venda! Vocês são cegos! Marx a previu!". Alguma coisa pelo menos ele previu. A verdadeira revolução é o capitalismo, que revoluciona todo dia a vida humana! O que nos cabe fazer não é só resistir, é opor algo. Esse algo se chama política. A política que me importa é a política contra esses poderes que são local e global. Ela é feita de forma articulada? Não.

\section{Thais Florêncio de Aguiar:}

Como assim?

\section{César Guimarães:}

O que põe no lugar? Não me importa! Não estou sozinho de novo, você sabe até quem eu estou citando, suponho que é Rancière, eu não faço ideia: a criatividade política se dá na vida. Não há nada de irracionalista nisso, apesar de alguém usar tolamente o termo. É na vida que se dá, na práxis que se dá! Nela se vai inventando, por análise concreta, no momento de agir, novas formas de fazer política contra o capitalismo que se implanta, se expande e continuará se expandindo. A previsão de Marx foi boa, mas não imaginava a longa e longa duração que o capitalismo teve, tem e terá. Zizek não é o único que diz isso, mas o faz muito bem, è ben trovato. O que está lá no Manifesto Comunista não é só uma boa previsão, mas uma previsão de longa duração que se aplica ao nosso momento mais que dantes. Hoje, finalmente, é global. Não era antes e ele não sabia. Encerrado na Inglaterra, Marx achava que o mundo, desde que se tornasse mais ou menos inglês, avançava.

\section{Thais Florêncio de Aguiar:}

As instituições funcionam?

\section{César Guimarães:}

Não importa. Elas legitimam. Elas legitimam! E os direitos? Os direitos humanos são conquistas. Quem quer que recentemente, aqui no Rio de Janeiro, tenha defendido e continue defendendo que seja punido quem matou Marielle Franco...

\section{Thais Florêncio de Aguiar:}

E Anderson Silva...

\section{César Guimarães:}


...faz mais pelos direitos humanos - e parem de mencionar isso como uma banalidade -, do que dezenas de ONGs etc. Direitos são conquistas de quem luta pelo direito. Quem luta pelo direito é quem se opõem a algo. Até nomes do liberalismo sabem disso. Isso é Rudolf von Ihering (veja você as coisas que li no primeiro ano de faculdade de direito para Hermes Lima...vou parar de citar grandes nomes). O que por no lugar do institucionalismo? Nada! Nada e tudo. Tudo é a criatividade contínua da política, como dizem Rancière e outros. Essa é a política da democracia, nunca alcançada e fundamental para a luta continuada. Acho que aprendi isso com Thais Aguiar, no seu conceito de "demofilia", escrito e publicado em livro.

\section{Thais Florêncio de Aguiar:}

Que generosidade.

\section{César Guimarães:}

Não é generosidade. Não conheço quem tenha usado esse conceito antes. Essa questão se impõe a muitos pensadores, é evidente. Mas não há ponto de partida no pensar filosófico. Os helenistas devem saber, vão buscar lá nos primeiros "pré-socráticos" etc. É o espanto, como comenta Aristóteles. Que o espanto sempre esteja a nos perturbar! A política é a realização do espanto diante da novidade. $O$ que fazer com o espanto? Pensar. Estou dizendo algo de novo ou algo de muito antigo? Eu queria deixar esse pequeno depoimento. Isso me importa porque tem a ver com a minha vida de ensino, com o que eu fiz. Não importa o que escrevi. Ainda que esteja merecendo todo cuidado por parte de pessoas próximas como você, Cristina e Pedro.

\section{Thais Florêncio de Aguiar:}

Quem lê atentamente seus textos aqui publicados pode notar a crítica desde sempre ao liberalismo.

\section{César Guimarães:}

A verdade é que as minhas preocupações com a crítica ao liberalismo sempre aconteceram. Mas sempre havia algo que ficava e que era mais significativo e que marcava minha presença no IUPERJ e depois no IESP. Algo de liberalismo sempre presente. De algumas pessoas, ouvi: "Bem! Você sempre me pareceu um liberal radical". Eu acho irônico, né. E ainda ouvi: "Pelo menos, um democrata radical". Eu respondia: "O que é ser democrata? Eu não sei". Mas houve um momento que essa palavra fazia todo sentido.

\section{Thais Florêncio de Aguiar:}

Em que momento?

\section{César Guimarães:}

Na ditadura! De alguma maneira, era palavra que contribuía para a luta contra a ditadura. Refiro-me a mim, a muitos amigos e colegas mais importantes que eu, inclusive, na luta e, eventualmente, no sofrimento. Não é meu caso, não sofri muito, não. Salvo a tristeza de viver em um lugar triste. Um lugar de silêncio. É Spinoza que se refere a uma cidade de silêncio, não é?

\section{Thais Florêncio de Aguiar:}

Pois é, a cidade como desolação, deserto, solidão.

\section{César Guimarães:}

Lugar onde a democracia não reina. O lugar do silêncio. É a paz do silêncio. Isso foi retomado por tantos autores, inclusive, por você em seu trabalho. De volta ao assunto, sim, havia essa coisa liberal que restava. Pois bem, não resta nada. Como uma canção francesa famosa, digo que deste amor do liberalismo não resta nada. "Que reste-t-il? Rien!" Nada! Gostaria de ter tempo para pensar, não simplesmente para criticar. Há uma vasta literatura crítica crescente, mas que não é dominante. De qualquer forma, em paradigmas dominantes, nada dominante domina tudo, a não ser na mais descabelada das teorias do totalitarismo que nada valem. Sempre há resistência, sempre há 
humanidade política. Não terei tempo, mas eu sei que tem gente que tem, não é, Thais? Tudo bem? O depoimento é para você.

\section{Thais Florêncio de Aguiar:}

Obrigada, Cesar... Bem, da ideia de crítica da teoria institucionalista e do liberalismo chegamos ao tema do golpe agora?

\section{César Guimarães:}

Pois é. Qualquer cidadão brasileiro interessado em alguma política e não favorável ao golpe de estado sabe que golpes são próprios de nossa república ao longo de mais de século. Em especial depois da limitada democratização posterior à constituição de 46. Quando não houve golpes ou tentativas de golpes?

\section{Thais Florêncio de Aguiar:}

Acho que é Florestan Fernandes que diz que o golpe é um ciclo permanente de contrarrevoluções preventivas num aspecto fundante de um processo conservador.

\section{César Guimarães:}

Eu deixaria isso tudo de lado. Sim, contrarrevolução preventiva é palavra forte. É simplesmente prevenção da democracia, da democratização crescente, que fala às massas, especialmente, às grandes massas populares e sindicais no período de 1961 a 1964. Parece que isso foi demais, não é verdade? Tivemos então 21 anos de duro ensinamento ao povo de que "isto não pode". Se Florestan sugere isso - e creio que sugere de alguma maneira -, acho perfeito.

\section{Thais Florêncio de Aguiar:}

Foi "demais" nesses últimos anos também?

\section{César Guimarães:}

Sim, mas esse "golpinho" que me fez mal, quando ocorreu mesmo? Já esqueci a data. Mas não é isso. Minha preocupação com o esgotamento do liberalismo vem de antes, de longa data. A crise de 2008, por exemplo, rebate sobre nós. A questão não vem daqui. Alguns não perceberam, inclusive, 0 Presidente da República, o Lula, não percebeu. Acho que era uma "marolinha". Era uma coisa que repercutiria cedo ou tarde. Hoje em dia, crises do capitalismo vão se deslocando para centros geográficos diversos. Naquela ocasião, nos governos do presidente Lula e, enquanto foi possível, da presidente Dilma, tínhamos uma política externa expressiva, que valia a pena acompanhar. Atualmente nem sei bem o que é, mas é melhor não saber. Havia muita preocupação com uma projeção de país, de grande país periférico com enormes pretensões. O chamado BRICS foi uma expressão disso, uma espécie de contraponto ao grupo dos oito, da Europa, reduzido ao grupo dos sete, não sei quando será o grupo dos seis, mas isso é problema entre eles. Briguem, mas não briguem demais não, porque a gente sabe como começa uma grande guerra (não, eu não falei isso, eu só pensei!). Essa desdemocratização, ainda que não chamem por esse nome, gerou preocupação no IESP, no IUPERJ, em muitos de nós. Mais recentemente, ensinando sociologia com Adalberto Cardoso, adotamos o título, que eu adorei, de democracia contra globalização. Hoje estou sobre ligeira impressão que tínhamos um pouco de diferenças a respeito do que chamamos de democratização, diferença essa que não tem nenhuma importância. Ele conduzia o curso que era, basicamente, sociológico, com um enorme brilho e eu fui atrás, com algumas leituras minhas. Há vários momentos no Iuperj que eu aprendi enormemente. Muito! E esse foi um.

Então, este golpe que houve aqui, me incomodou. Eu acho até que escrevi uma mensagem longa de email para uma rede de 30 amigos que acabou parando no site Carta Maior. Não sou colaborador e creio que chegou ali por conta de meu amigo Sebastião Velasco e Cruz. Fiquei feliz, embora não tenha escrito para isso.

\section{Thais Florêncio de Aguiar:}


Como não pudemos registrar sua palestra acerca da teoria de golpe do estado ministrada na UERJ, gostaria que falasse sobre o tema. Era um momento em que havia forte pressão por parte de setores do governo e da sociedade contra o uso da palavra "golpe". Em sua fala na UERJ, você tratou desse tema trabalhando referências da teoria política. Foi isso?

\section{César Guimarães:}

Bernardo Ferreira e João Trajano me convidaram para falar sobre o golpe. Tendo pessoas melhores que eu para falar sobre o assunto, resolvi falar de coisas antigas, do surgimento do conceito. Por aí cheguei ao nada desconhecido Gabriel Naudé. Não foi uma palestra, foi uma conversa com amigos. Nunca me senti bem em palestras para público grande, em mesas-redondas, congressos, encontros. Isso me inibe mesmo, particularmente, em uma situação em que tenha que falar qualquer coisa em dez ou quinze minutos. Bem, não há nenhuma novidade de que a grande imprensa brasileira (ou a mídia) apoiou o golpe. Sempre foi assim. A grande imprensa passou a ser, crescentemente no mundo todo, um negócio. São empresas. Não me consta que empresas, salvo o melhor juízo, sejam contra o que lhes dá lucro. Mas voltando à conversa que tive com amigos na UERJ, tentei remotar a ideia de razão de Estado. Tenho a impressão - apenas acho, porque eu leio pouco -, de que a ideia de razão de Estado se estuda pouco. Melhor, se estuda muito, mas a coisa vai de outra maneira. Depois de pedir a Bernardo para fazer uma incursão qualquer, como sempre, eu garatujei umas quatro ou cinco folhas. Li coisas riscadas a lápis em uma edição em inglês do famoso livro de Meinecke sobre a ideia de razão de estado na historia moderna. (A propósito, livro que o tradutor resolveu chamar em inglês de Maquiavellism: the doctrine of raison d'état and its place in modern history $^{2}$. Não tem problema chamar de Machiavellism. É só maldade com Maquiavel.) O tema faz parte de toda reflexão que corta parte do século XVI e todo o século XVII e acompanha a consolidação do Estado Nacional, quer dizer, me perdoem, do Estado Absoluto. Não tem nada de nacional! A França de Luís XIII e Luís XIV; a conturbada Inglaterra, onde está contido, pela assim chamada Revolução Gloriosa; a Espanha, dos reis católicos e seus sucessores; a Itália nunca se comportou como tal; a Prússia, nos idos de 1700, onde tomaram o poder e montaram ali um negócio meio complicado; e o resto da assim chamada Alemanha - desculpe chamar de resto, mas eram Estados dispersos, como você sabe, postos juntos sob a mão de ferro de Bismarck tardiamente; esquecemos a Suécia de Gustavo, e por aí vai.

\section{Thais Florêncio de Aguiar:}

A questão da unidade.

\section{César Guimarães:}

Sim, questão que alguém nos lembra ser a acumulação primitiva da política: a subtração do poder de potentados locais por um poder central. Essa é a ideia de Althusser, presente em um de seus mais notáveis textos, Solitude de Machiavel, versão escrita de uma conferência de 1977. Quer dizer, trata-se da expropriação do poder feudal por algo novo, algo barroco, absolutista, em que a palavra "soberano" passa a fazer sentido. Esse termo, afinal, é consolidado por Bodin no final do século XVI, cabendo aí falar do soberano. O soberano então significa que o Papa tem um lugar diferente. Ele é posto em um lugar: um chefe de estado, um senhor de estado, um estado papal. Voltando a Meinecke, ele dedica um capítulo de seu livro a Gabriel Naudé, dando a devida importância a Naudé, ou melhor, a seu livro de 1639. Interessante que a obra principal de Naudé não trata disso. Foi bibliotecário, primeiro na Itália, depois na França, o que Ihe permitiu escrever uma bibliografia do poder, ou seja, uma revisão do que havia de disponível entorno das mais diversas reflexões sobre a política de seu tempo.

\section{Thais Florêncio de Aguiar:}

Secretário de cardeais de Roma, bibliotecário do cardeal Mazarino, não é isso?

\section{César Guimarães:}

\footnotetext{
${ }^{2}$ Nota da entrevistadora: Die Idee der Staatsräson in der neueren Geschichte (A ideia de razão de estado na história recente) é título original do livro de Friedrich Meinecke em alemão.
} 
Mazarin ou Mazarino, como preferir. Maria de Médici, Mazarino, e por aí afora, são todos italianos. A Itália fornecia estadistas. Tem muitos estadistas que não podiam ficar lá, porque lá não tinha Estado, ora. Evidentemente que essa belíssima observação não é minha, mas de Fernand Braudel em seu livro O modelo italiano. Voltando a Naudé, ele consolida o conceito de golpe de estado - "les coups d'état" - leitura de resto nada incomum no século XVII, lido por católicos e por pensadores absolutistas, combatido por monarcômanos. Todos aqueles que se situavam pró e contra 0 absolutismo que lá se impõe, mas não sem luta. Se impõe na França, não sem derrota das frondas. Como você sabe, derrotar as frondas ou levantes da nobreza era o trabalho do qual se ocupava Richelieu. Ele lá tinha tempo de pensar em golpe de estado! Estava dando um por dia! Era uma leitura bruta de $\mathrm{O}$ príncipe, como de resto comum no século XVII. Uma leitura a justificar o que é referido como a criatividade do príncipe em interromper o curso das coisas no melhor interesse do Estado definido, é claro, pelo príncipe que, a essa altura, é o soberano. Esse é também um conceito novo, criado por Bodin. Quanto tempo antes do livro de Naudé escreve Bodin A República? Poucas décadas antes ${ }^{3}$.

\section{Thais Florêncio de Aguiar:}

Em que sentido exatamente a leitura de Maquiavel é bruta?

\section{César Guimarães:}

A leitura é tão bruta que o nosso Naudé dá como exemplar clássico de golpe de Estado o massacre de São Bartolomeu, além do esmagamento das frondas (Richelieu deve ter olhado isso de lado, pensado "por favor, não venha me falar, eu estou praticando isso, ninguém percebe", mas também não passou recibo, até porque também é um teórico político, bem sabemos). O massacre de São Bartolomeu é o exemplo mais notável. Ele dá muitos outros. Esse massacre de huguenotes em Paris havia acontecido poucas décadas antes. Portanto, um exemplar do maquiavelismo brutal do absolutismo barroco - é a palavra correta em política do período. Isso será logo consagrado pelo grande, ou pequeno, como você preferir, Luís XIV: "eu sou o Estado, eu sou o Príncipe". Nem precisa dizer isso. Por que é bruto? Maquiavel é muito usado dessa maneira, da mesma maneira que ninguém está nem aí para ler o livro da República, os comentários não são sobre Tito Lívio, o que se lê é Tácito... A ideia de que um Maquiavel republicano, que sempre teria sido lido por toda uma linhagem, foi invenção recente da escola de Cambridge e de outros que cai muito bem. Chegando aos Estados Unidos, as pessoas ficam felizes em não serem meramente lockeanas e leem Montesquieu na Revolução Americana, que passou a ser uma revolução - tudo bem, é isso mesmo, a maior revolução contra os ingleses, contra o imperialismo inglês, vamos ficar à vontade. Bela invenção anglo-saxônica recente. Teve impacto? Sim, em Harrington, só que não vem ao caso aqui (leia a literatura pertinente, eu tenho mais o que fazer, a essa altura já li). Isso coincide com uma coisa muito notável, que é a assim chamada história das ideias, praticada por muita gente, há muito tempo, das mais diversas maneiras. Então, por que é bruta? É bruta porque quem lê assim Maquiavel esquece o famoso capítulo em que a crueldade jamais é justificada. Nesse capítulo lemos que não podemos chamar de virtuosas ações praticadas por mera crueldade, como para satisfação pessoal do Príncipe. Isso não é o exercício da virtú tal como deve ser. Mas esse capítulo inteiro sobre a crueldade é esquecido frequentemente. Ora, a noite de São Bartolomeu é um caso clássico de brutalidade e crueldade, foi uma matança! Não foi cometida para o melhor interesse do Estado coisíssima nenhuma. Foi uma matança! Livra-se, certamente, do adversário, num golpe de Estado, sem ter menor ou maior interesse do Estado envolvido aí. Negociação que estava na ordem do dia, sem engendrar nada de bom. Lá se vão os capetas! - a palavra é mordaz! Fala-se nos capetas porque, como você sabe, Henrique voltou bem armado, converteu-se ao catolicismo e se tornou Henrique IV, rei de França. E temos: "Paris vale uma missa!". Independentemente desses comentários, a ideia de golpe de Estado está aí, quem dá o golpe é o Estado. Para quê? Para o melhor interesse do Estado. Quem define? O próprio Estado.

\section{Thais Florêncio de Aguiar:}

Definido, supostamente, para assegurar a preservação do Estado, do "bem geral".

\footnotetext{
${ }^{3} \mathrm{O}$ livro de Bodin é publicado em 1576.
} 


\section{César Guimarães:}

Isso. Sempre é para o bem geral.

\section{Thais Florêncio de Aguiar:}

Agindo contra o direito comum ou verdadeiramente comum.

\section{César Guimarães:}

Isto! Contra o direito verdadeiramente comum, se é que existe. Aliás, o golpe de Estado que se preza não se chama pelo próprio nome, não é isso? Até no Brasil sabem disso. É sempre alguma coisa assim como "movimento de retorno aos quadros constitucionais vigentes". Gostou? Isso é o manifesto geral de Lott contra o movimento que objetivava impedir a posse do presidente eleito, Juscelino. Quem gostou chama de "contragolpe", mas é sempre um golpe. Eu gostei, mas sei que o contragolpe é golpe...É engraçadíssimo o nome, pense bem: "movimento de retorno aos quadros constitucionais vigentes". Se são vigentes, não se retornam. Então é um nome notável pela sua qualidade, seu oximoro! Todo mundo chamou a atenção disso na época, particularmente os udenistas, aqueles que eram a favor do golpe.

\section{Thais Florêncio de Aguiar:}

Do tempo de Naudé aos nossos tempos, a ideia de golpe de Estado se transforma, passando pelo Iluminismo, pela Revolução Francesa...

\section{César Guimarães:}

Sim, vamos "dar um pulo"? Vamos tomar a Revolução Francesa como um marco do nascimento de uma ideia, a ideia de representação política. Veja bem, o governo é apresentado como qualquer coisa de representativo, mesmo que o termo não seja usado, essa noção está por ali. Está, por exemplo, em certa leitura de Rousseau; nos textos do principal constitucionalista do início da Revolução Francesa, Sieyès; logo adiante, em Benjamin Constant; e logo à frente é usada diretamente em uma obra notável de John Stuart Mill - me refiro ao livro O governo representativo. Nele, o uso do conceito de democracia é notável. Ele escreve: "a democracia não é governo da maioria, é o governo de todos". Que maravilha! Eis aí um movimento liberal denso, que ele está criando. Então vejamos: como podemos usar a palavra golpe de Estado? Pense bem: o conceito não faz sentido.

\section{Thais Florêncio de Aguiar:}

Não faz mais sentido depois dessa invenção de democracia como governo representativo.

\section{César Guimarães:}

Sim, porque se o Estado é de alguma maneira representativo, como ele pode golpear-se a si mesmo? Para usar, enfim, as contorções conceituais de Rousseau: como golpear-me a mim mesmo? Suicídio político? Contudo, a Revolução Francesa - para ficar só nela - é uma sucessão de golpes. Um golpe atrás do outro. Termidor é o último de que, finalmente, os liberais gostam! É o momento de origem de muitos autores que escrevem tão bem na França, que são supreendentemente interessantes, muito embora, convenhamos... (Benjamin Constant não é editado há mais de cem anos na França. Isso é absurdo! Mas é verdade. Diz-se que é porque os marxistas não se preocupavam ou não deixavam. Não é só isso. Havia liberais recentes da qualidade de um Raymond Aron - já que é para falar de gente importante e séria -, que ocupavam esse espaço.) Voltando à Revolução, ocorre um golpe atrás do outro, até que, finalmente, o primeiro Bonaparte dá o mais famoso golpe, cria o Consulado, torna-se o primeiro-cônsul, e, finalmente em 1804, se faz coroar como imperador. Um golpe. Ele chama ainda o Papa: "Vem cá, Papa, me coroa!". Quem pinta essa cena é [Jean-Louis] David, não é? Uma tela enorme, que ocupa imensa parede do Louvre, intitulada 
"A coroação de Napoleão". Golpe atrás de golpe. Como vamos chamar isso? Que tal uma homenagem a algum autor que escreveu "A fantasia desfeita" ${ }^{\prime \prime}$ ?

\section{Thais Florêncio de Aguiar:}

A fantasia desfeita?

\section{César Guimarães:}

Sim. Há golpes de Estado em regimes representativos, sejam eles restritos, sejam eles mais amplos. Como? Hoje, alguém diria: "não. Isso não seria possível, porque, afinal o Estado é representativo de todos". Não é verdade? Não é, não. Podemos ler, por exemplo, a brilhante crítica à ideia de representação de Tolstoi. Deixemos para lá. As pessoas vivem dessa fantástica noção de representação que, às vezes, mais parece uma espécie de fantasmagoria. Devo levar a sério de alguma maneira, mas não consigo. São meus defeitos. Um bom conceito para falar disso - pode ser qualquer outro - é bonapartismo, conceito consagrado por Marx (não é o primeiro autor a usá-lo). 0 que caracteriza? O golpe não é mais dado pelo Estado. Pode ser dado a partir do Estado ou contra quem está no Estado.

\section{Thais Florêncio de Aguiar:}

Mas o golpe sempre é dado dentro do Estado.

\section{César Guimarães:}

Sim. No contexto da elite de poder, no sentido amplo. Napoleão Bonaparte dá uma "rasteira" em Sieyès (a linguagem não é minha, é de Godechot), sendo mais esperto que o muito esperto Sieyès. A partir desse momento, ele diz "eu sou o maior dos jacobinos". Logo ele, que havia reprimido os jacobinos! É um primor. O resto é Guerra e Paz. Temos aí uma porção de conceitos mais recentes, importantes ou não: carisma, plebiscitarismo, apelo às massas. A propósito, há massas, não é? "Aujourd'hui, on ne peut gouverner qu'avec les masses", diz Luís Napoleão, e se torna Napoleão III. A frase é literal: hoje em dia não se pode governar senão com as massas. Que massas? As massas são as massas, essa coisa que se plasma. Quem são massas que apoiam o nazismo? Já há algum tempo os historiadores sabem muito bem que massas são essas. Não são as massas em geral, aquelas de filme de Fellini (aliás, que maravilha, Fellini!) ou de Ettore Scola (outra maravilha!). Não é assim. Há massas que não estão entre as massas, assim como há passeatas que são de certo tipo de massa e há passeatas que são de outro. Como o pré-golpe mais recente no Brasil nos fez assistir. Você via na televisão - mesmo que ela não quisesse mostrar - que tipo de pessoa estava nas passeatas. Era fácil ver. Refiro-me ao momento de "Abaixo Dilma", "Derruba a Dilma" e todas aquelas bandeiras brasileiras.

\section{Thais Florêncio de Aguiar:}

O bonapartismo pode constituir um golpe de Estado no interior de governos representativos?

\section{César Guimarães:}

Temos golpes famosos nos tempos de governo representativo. O bonapartismo é o nome de um deles. Há uma variante: a variante de Bismarck que, a partir da Prússia, unifica a Alemanha. Assim, ele acaba com alternativas que são perdidas em 1848. O bismarckismo, aliás, é termo utilizado por Hélio Jaguaribe em certa proposição sobre o governo que melhor cabe para o tal desenvolvimento. Deve ser um conceito também notável, mas que tenho enorme dificuldade de entender desde garotinho. Claro, o fato de eu não entender é burrice minha! Em um determinado momento de sua maravilhosa obra - não precisa concordar com ela, aliás, certas coisas tem que ser lidas, a despeito de se concordar com elas -, Hélio Jaguaribe diz que a saída para o desenvolvimento do Brasil é "o bismarckismo". Ele explicava o que era, para o horror das pessoas que achavam que bismarckismo era autoritarismo. A variante "golpes militares" - assim chamados porque assim o são - é apenas

\footnotetext{
${ }^{4}$ Referência ao livro que Celso Furtado dedica ao período de experiência democrática compreendido entre o governo Juscelino Kubistchek e o golpe civil-militar de 1964, considerando esse período como marcado pelo desenvolvimento econômico e dinamismo social e político.
} 
uma variante que ocorreu em lugares como América Latina, Grécia e por aí afora. Evidentemente, a principal variante da "fantasia desfeita" são os fascismos, que são alimentados pelas potências vitoriosas na Primeira Guerra Mundial. Nos países da fronteira europeia com a recém-emergente União Soviética, Clemenceau e outros estabelecem o cordon sanitaire. Nesses países, o fascismo é inspirado: na Áustria, na Eslováquia, na Croácia etc. Trata-se de fascismos próprios. É claro que, a essa altura, em 1922, já aparece o que será o fascismo propriamente dito: a palavra fascio é usada na Itália diretamente. Mas são todos fascismos. Aliás, as elites políticas desses países agora retomam uma tradição - são as elites, não falemos mal do povo. Nesse momento, isso ocorre na Hungria. Há dúvidas? Há tempos ocorre na Polônia. Há sempre a presença de um partido de extrema direita muito forte e um partido de direita no poder. O que há na Itália agora? É complicado, não teve golpe nenhum lá, houve eleições etc e tal. Os três maiores partidos de direita (extrema direita, para ser mais claro), ganharam "apertado", mas ganharam. Só que o maior deles, o de Berlusconi, resolveu fazer oposição, até porque o grande líder não pode participar de governos. Assuntos de direito penal. Então a Liga [Liga Norte] e o M5E [Movimento 5 Estrelas] governam a Itália. Para primeiro ministro, escolheram um homem neutro, um economista de grande experiência no trato com a Comissão Europeia e com a Banca. Como é sabido, todos os técnicos são neutros, obedientes aos ditames da racionalidade, que é a Razão. Então está tudo bem no melhor dos mundos possíveis.

\section{Thais Florêncio de Aguiar:}

Não é do "extremo-centro", como você diz?

\section{César Guimarães:}

Ele é do extremo-centro. O extremo-centro é um novo termo, não é? É Macron, n'est-ce pas? Macron, que não é nada, é produto do marketing, como o eleitorado já sabe. Ele quer a União Europeia. Seu vínculo com a Alemanha sendo forte, isso mantém a União Europeia, que é um horror! Essa não é União Europeia da fantasia de Habermas. Pura fantasia. E de outros democratas e liberais - dê o nome que você queira dar. Habermas, a propósito, continua produzindo e sabe-se Deus com que idade. Quando fala de política fora da Europa é um horror. Mas quando fala da Europa não há causa importante em defesa da qual ele não tenha escrito.

\section{Thais Florêncio de Aguiar:}

Queria que você retornasse à histórica relação entre golpe de Estado e o fascismo.

\section{César Guimarães:}

$\mathrm{Na}$ Hungria houve um levante comunista (não foi uma revolução) que levou ao poder Bela Kun. $\mathrm{O}$ experimento, digamos assim, durou poucos meses, e logo foi derrubado. Lukács fez parte, quando jovem, desse governo que dura poucos meses, sendo derrubado por um fascista de origem militar chamado Miklós Horthy, com apoio aberto da França e outras potências europeias. Eles não tinham o menor problema em apoiar fascismo algum. Dedicavam-se a conter e destruir o comunismo, 0 terrível perigo criado pela jovem União Soviética, que recebeu apoio entusiástico de movimentos e partidos de esquerda na Europa, nos Estados Unidos, na América Latina, aí se incluindo o Brasil, e por aí vai. Nada incomum que à contenção e destruição se seguisse referência à democracia, à legitimidade, etc., não faltando a convocação de eleições bem conduzidas. Hitler ainda não chegara, mas Mussolini chegou ao poder com sua Marcha. 22? Na Áustria, em território agora tão limitado, já que 660 anos de Império Habsburgo se esvanesceram com a derrota na Grande Guerra, a cidade de Viena não se tornou apenas espaço livre para novas manifestações artísticas, filosóficas, de teoria econômica, mas também como palco de outra grande inovação socialista (que se soma à dos soviéticos), o longo governo municipal da Social Democracia (SD) conduzido pela SD de Bauer, de Adler, de Renner, do austromarxismo, enfim. "Não se faz comunismo municipal", advertia a SD, mas fato é que, por mais de dez anos, a população de Viena teve educação pública, saúde mantida pelo governo, previdência social que nada lembrava a impostura de Bismarck, além, é claro, dos mais amplos direitos individuais e liberdades públicas (a grande propriedade urbana foi fortemente tributada, como deve ser!), com sucessivas eleições... municipais. No restante da Áustria predominavam os conservadores, os liberais, a democracia cristã, com amplo e habitual apoio da 
burguesia e da nobreza ressentida. A crise de 29 facilitou o golpe austro-fascista contra Viena, que foi tomada pelas tropas e milícias de Dolfuss, com o apoio externo esperado; seu governo contou com a alegre participação de um "inovador" da teoria econômica e da teoria política, o "grande" von Mises...Contudo, ao Norte, a esquerda sueca absorveu a lição, a que não faltava, como em Viena, uma leitura atenta de Bernstein, comunista crítico, marxista sem dialética, como os vienenses. Data de 1932 a repressão à bala, por ordem do rei local, dos grevistas de Adalen, cidade de alguma importância. O povo sueco respondeu com greve geral que paralisou todo o mundo urbano e teve apoio de trabalhadores rurais e pequenos proprietários - uma inusitada coalizão num contexto revolucionário. A partir daí começa a fazer algum sentido a tal de transição lenta para a social democracia, versão oficial acalentada pela SD já no poder, estória tão cara ao patriotismo sueco. Tudo bem, mas patriotismo não é história nem ciência política.

\section{Thais Florêncio de Aguiar:}

Como você gosta de lembrar: quando os fascistas aparecem, os liberais se calam. E nessa relação, aparece a associação também entre golpe e legalidade.

\section{César Guimarães:}

Em todos esses momentos, os golpistas sempre respeitam a legalidade. Luís Bonaparte foi eleito presidente por uma notável maioria em 1849 na eleição presidencial da segunda república. Formou um amplo ministério. Para o ministério das relações exteriores, que tratava dos assuntos argelinos, chamou um certo Alexis de Tocqueville, que inclusive escreveu sobre a Argélia. (Esse trabalho é um horror, mas não era racista. Imagina! É coisa de época! Naquela época, você podia chamar as pessoas de todo jeito, "todo mundo falava assim". Está bem. Todo mundo, não é mesmo, menos os argelinos, os bérberes etc.). Depois, Napoleão diz "não pode se governar senão com as massas". Em geral, a justificativa do golpe de Estado em governo representativo sempre apela para o melhor interesse do Estado. (Digo, em geral, porque não vamos chamar atenção para o que não vale a pena. O golpe dos coronéis em 1964 evidentemente é o que é. Ele se justifica à la Carl Schmitt, porque a revolução justifica a si mesma. Não diz que recupera a democracia, mas que impede que ela seja destruída, como sempre está se impedindo algo pior..). Falar em melhor interesse do Estado é estranho. Mas é sempre assim: o golpe respeita a legalidade e frequentemente é legítimo. Pois bem, o evento agora posto em perspectiva no Brasil, não falo dos outros golpes, é a mesma coisa. Os poderes da República, refiro-me, em última instância, ao judiciário aprovaram (a propósito, não me recordo de ter eleito um judiciário)! Tudo é muito bem feito. E daí? Agora, vou viver ao final da minha vida uma justificativa jurídica de atos de natureza rigorosamente política? Esse legalismo de que me livrei na faculdade de Direito? Se alguns cientistas políticos ou sociólogos repetem isso, o que eu posso fazer? "Mas os juristas dizem isso..." Muitos, certamente. Mas eu pergunto: quem disse que os juristas, em geral, tem algo contra posições conservadoras e até golpistas? Onde isso aconteceu? É natural que um notável brasileiro, que há pouco faleceu - respeitemos - tenha sido um lutador contra a ditadura militar e um defensor triste do golpismo mais recentemente.

\section{Thais Florêncio de Aguiar:}

O senhor Hélio Bicudo.

\section{César Guimarães:}

Exato. Respeitemos. Respeitemos. O que acontece em 1961? As massas ativadas pela política passaram do limite. Deixaram de ser passivas, entraram em atividade e fizeram política. Não me venha com a explicação populista que também nesse caso ela não vale nada. Com todo o respeito a quem formulou, porque não são pessoas pouco sérias. As massas não eram manipuladas coisíssima nenhuma. O caminho era de mão dupla. Para o bem ou para o mal. Os limites foram impostos. Mas, afinal, quem é o demos? Era somente a classe média até então o demos possível? Wanderley Guilherme dos Santos chama a atenção para a ideia muito interessante de oligarquia representativa na Primeira República. Então, quando isso acabou, instaurar a tal democracia representativa não pode, não é mesmo? Dizem que devemos ir com cuidado, modus in rebus, ponto por ponto. O que ocorreu com o governo Lula, o governo Dilma, o governo do Partido dos Trabalhadores (PT) (partido esse ao qual eu não me filio, nem nunca tive menor vontade de me filiar, porque não é minha 
tradição)? Evidentemente, de alguma maneira, de forma errada ou certa, grandes massas - inclusive as que não são necessariamente de trabalhadores, mas apenas - como é o nome? - o povo em geral (os pobres que não deviam entrar em supermercado, em shopping center) se interessam e se movimentam de tantas e várias formas não diretamente partidárias. Existe, e continua existindo, tantas formas organizativas em lugares aonde a política só chegava como uma forma tardia de clientelismo e violência. Muitas populações faveladas, por exemplo, no Rio de Janeiro e tantas outras partes. Alguns consideram que movimentos de mulheres e de gays propõem coisas enlouquecidas, afrontando a moral e os bons costumes. É tudo o que ocorre: a desmoralização de costumes, juntamente com manifestações inesperadas e não diretamente políticas. Entenda o ponto, não são como em 1961, porque não são comícios. Mudou. A política sempre muda. Há sempre formas criativas. Não há governo que crie formas criativas, mesmo que o queira - me refiro ao governo Lula. Um automóvel novo não cria nada. "O consumo é cidadania!". Não, consumo não é cidadania. Consumo é consumo. Cidadania é conceito muito elástico, como populismo. Serve para tudo e se vê perdido. Quem cria são as próprias manifestações populares estudadas por tantos sociólogos.

\section{Thais Florêncio de Aguiar:}

Muita coisa mudou. Mas nesse momento nos remetemos muito àquele momento pré e pós golpe da década de 60.

\section{César Guimarães:}

Sim, há semelhanças e diferenças. Não sou a melhor pessoa para elaborar isso. Veja, em ambos os casos, o inesperado é a presença do demos. Aquilo que Spinoza, no sentido positivo, conferia à multidão. A multidão - como eu aprendi com você - nem sempre é boazinha coisa nenhuma. Ela pode fazer coisas terríveis! Brutalidades terríveis! Não precisa ler Le Bon para saber isso. Nele, é só ruína e não é bem assim. Também não cabe a "consagrada multidão" das fantasias de Antonio Negri (ainda que parte de sua obra seja interessante, por favor, vai devagar!). Nos anos 60, sucedeu de uma forma mais política ou sindical. Nesses governos recentes, ocorre de outra maneira. Há a política e o sindical também - a CUT continua presente e a classe operária, lamento muito informar, tem a mania de não acabar.

\section{Thais Florêncio de Aguiar:}

A manifestação do demos está presente e nunca é a mesma. De qualquer forma, é muito pertinente lembrar os golpes nesses dois momentos de 1964 e 2016.

\section{César Guimarães:}

Sim. Foram contra a criatividade da política que importa. A política democrática do demos, que varia de tempo para tempo, afetando os donos do poder que controlam as instituições. Isso marca esses dois momentos bem diferentes. Golpes existem para conter isso. Não vamos voltar para trás. Não adianta reprimir. Foi preciso um período longo de 21 anos de repressão para conter isso. Ao fim e ao cabo, logo ressurgiu a criatividade política, ainda que de forma torta. Não foi pela violência. Ela não era possível e, lamento muito, erraram os que a praticaram. Ressalto que não tenho bom motivo para gostar da repressão contra a luta armada, pelo contrário, lamento muito. Logo ressurgiu como movimento sindical, movimento esse que não foi inventado pela CUT e cuja tradição esquecemos. Mas não importa, ressurge de alguma maneira. Como? Não sei a forma que tomará a reorganização do demos. Só sei que é impossível impedi-la. Não sei, por exemplo, a forma que tomará aquilo que em determinado momento foi chamado de "ocupa". Não é uma coisa de origem americana, o ocupar Wall Street. Ocupar tornou-se verbo internacional, usado inclusive no Brasil em relação a universidades, a fábricas etc. São manifestações. Quem pensava nisso? Ninguém. De onde surgiu? De alguma mente diabólica? Pensando bem, não foi.

\section{Thais Florêncio de Aguiar:}

Quer dizer, os golpes jamais vão impedir essa criatividade política do demos.

\section{César Guimarães:}


Não. Podem continuar respeitando a legalidade. Não faço a menor ideia se não haverá mais golpes militares. Por quê? Ora, se for preciso haverá golpe militar aqui, no Chile, na Grécia. Qual é a novidade? Nos anos 70, lembro que nas minhas aulas no IUPERJ as pessoas ficaram muito incomodadas comigo quando, falando sobre o golpe no Chile, disse que, dependendo das circunstâncias, o Chile é o futuro da Suécia. "Professor, isso não vai acontecer!". Eu não faço a menor ideia. $\mathrm{O}$ mundo não está pré-determinado. $\mathrm{O}$ certo é que golpes são brutais, passam e se justificam sempre. Mas, não adianta, frequentemente são dados para isto: para conter o demos. Mas é impossível contê-lo. Impossível conter isso que eu acho que deve ser estudado como democracia. É o nome que tem. Não lhe parece, Thais? Eu sei que lhe parece. Muito de perto. Essa parte só, o resto não. Eu acho que se eu tiver mais um ano ou dois, é sobre isso que eu quero ler. É o que importa...

\section{Thais Florêncio de Aguiar:}

Você terá. E mais do isso.

\section{César Guimarães:}

Ainda nos espantamos diante da política. O que são esses pequenos eventos diante do que importa realmente, que é a luta continuada do demos?

\section{Cite esta entrevista}

GUIMARÃES, César. Entrevista conduzida por Thais Florêncio de Aguiar. Revista

Estudos Políticos: a publicação eletrônica semestral do laboratório de Estudos Hume(a)nos (UFF). Rio de Janeiro, Vol. 9 | N. 1, pp. 5 -19, Julho, 2018. Disponível em: http:// revistaestudospoliticos.com/

\section{Notas}

1. Professora no Departamento de Ciência Política do Instituto de Filosofia e Ciências Sociais (IFCS) da Universidade Federal do Rio de Janeiro. Pós-doutora pelo Departamento de Ciência Política da Universidade de São Paulo (USP). Em Pós-doutoramento pelo Instituto de Estudos Sociais e Políticos (IESP) da Universidade Estadual do Rio de Janeiro. 